\title{
PROFIL PENGGUNAAN ANTIBIOTIKA UNTUK PENGOBATAN ISPA NONPNEUMONIA DI PUSKESMAS KEDIRI II TAHUN 2013 SAMPAI DENGAN 2015
}

\author{
(PROFILES THE USE OF ANTIBIOTICS FOR ACUTE INFECTIOUS NONPNEUMONIA \\ DISEASE IN PUSKESMAS KEDIRI II PERIOD 2013 UNTIL 2015)
}

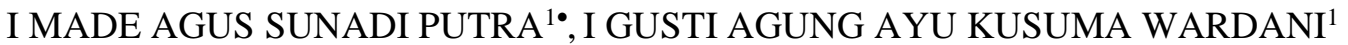 \\ ${ }^{1}$ Akademi Farmasi Saraswati Denpasar, Jalan Kamboja no.11A, Denpasar
}

\begin{abstract}
Abstrak: ISPA adalah penyakit infeksi akut yang menyerang salah satu bagian atau lebih dari saluran nafas. Infeksi pada saluran pernafasan merupakan penyakit yang umum terjadi di masyarakat, dan penyebarannya sangat mudah dan cepat. Secara umum penyebab dari infeksi saluran nafas adalah berbagai mikroorganisme, namun yang terbanyak akibat infeksi bakteri dan virus. Pengobatannya juga disesuaikan dengan penyebabnya. Penggunaan antibiotika diperlukan apabila penyebab penyakitnya sudah dipastikan bakteri. Kenyataannya dimasyarakat penggunaan antibiotika begitu mudah. Hal ini menimbulkan kekhawatiran terjadinya pengobatan yang tidak rasional dan kemungkinan terjadinya resistensi. Penelitian ini mengumpulkan data yang disajikan sedemikian rupa, untuk menggambarkan penggunaan antibiotika untuk pengobatan ISPA nonpneumonia di Puskesmas Kediri II. Penelitian ini dilakukan dengan metode deskriptif observasional, yaitu penelitian berdasarkan data-data yang sudah ada tanpa melakukan perlakuan terhadap subyek uji. Data diperoleh dari hasil penghitungan resep yang diberikan kepada pasien yang didiagnosa ISPA nonpneumonia, seperti pilek (common cold), sinusitis, faringitis, tonsilitis, laringitis dan ISPA lainnya yang tidak spesifik, yang berobat di Puskesmas Kediri II pada tahun 2013 sampai dengan tahun 2015. Dari penelitian yang dilakukan diperoleh hasil penggunaan antibiotika tahun 2013 sebesar 86,16\%, tahun 2014 sebesar 88,61\% dan tahun 2015 sebesar 82,73\%, dengan Amoxycillin menduduki peringkat tertinggi penggunaan antibiotika yaitu sebesar 92,76\%, Cefadroxil 4,19\%, Ciprofloxacin 1,34\% dan Cotrimoxazole 1,71\%.
\end{abstract}

Kata kunci: ISPA, Nonpneumonia, Antibiotika.

Abstract: ISPA is an acute infectious disease that attacks one or more parts of the respiratory tract. Infections of the respiratory tract is a common disease in the community, and the spread is very easy and fast. Generally, the causes of respiratory tract infections are a variety of microorganisms, but the most due to bacterial and viral infections. The treatment will be adjusted to the cause. The use of antibiotics is needed if the cause of the illness has been ascertained bacteria. In fact, the community use of antibiotics is so easy. This raises worries the treatment of ARI is an acute infectious disease that attacks one or more parts of the respiratory tract. Infections of the respiratory tract is a common disease in the community, and the spread is very easy and fast. Generally, the causes of respiratory tract infections are a variety of microorganisms, but the most due to bacterial and viral infections. The treatment will be adjusted to the cause. The use of antibiotics is needed if the cause of the illness has been ascertained bacteria. In fact, the community use of antibiotics is so easy. This raises worries rational use of inappropriate medication and the possibility of resistance. This study collected data that is presented in such a way, to illustrate the use of antibiotics for the treatment of ARI non-pneumonia in Puskesmas Kediri II. This research was conducted with descriptive observational method, which is a research based on data that already exists without the treatment of the test subjects. Data obtained from the calculation (recipe given to patients diagnosed with ARI non-pneumonia, colds (common cold), sinusitis, pharyngitis, tonsillitis, larigitis and ISPA that is not specific, are treated at the PHC Kediri II in 2013 until the year 2015. From research conducted use antibiotics result in 2013 amounted to $86.16 \%$, amounting to $88.61 \%$ in 2014 and 2015 amounted to $82.73 \%$, the highest rank Amoxycllin use antibiotic that is equal to $92.76 \%$ of cefadroxil $4.19 \%$, Ciprofloxacin Contrimoxazole $1.34 \%$ and $1.71 \%$.

Key Word: ISPA Nonpneumonia, Antibiotics.

\section{PENDAHULUAN}

Infeksi pada saluran pernafasan merupakan penyakit yang umum terjadi di masyarakat. Secara umum penyebab dari infeksi saluran nafas adalah berbagai mikroorganisme, namun yang terbanyak akibat infeksi bakteri dan virus. Infeksi saluran nafas dapat terjadi sepanjang tahun, meskipun

• email korespondensi: agussunadi@gmail.com 
beberapa infeksi lebih mudah terjadi dimusim hujan. Pada usia dini (anak dan balita) umumnya paling sering terkena penyakit infeksi saluran nafas. Hal ini dikarenakan daya tahan tubuhnya yang masih rendah, juga karena faktor gizi yang kurang.

Pemerintah Indonesia melalui Departemen Kesehatan Direktorat Jenderal Pengendalian Penyakit dan Penyehatan Lingkungan (P2PL) telah menetapkan pedoman pengendalian penyakit infeksi saluran nafas akut yang mengacu pada ketentuan yang ditetapkan WHO. Salah satu langkah yang dilakukan adalah dengan memberikan pendidikan dan pelatihan kepada tenaga kesehatan (dokter, perawat, bidan dan penyuluh kesehatan). Tujuannya adalah untuk menekan penyebaran penyakit saluran pernapasan akut, terutama untuk penyakit Pneumonia pada balita, agar dicapai tingkat pengobatan yang optimal dan meningkatnya derajat kesehatan masyarakat. (Depkes. 2006)

Selain pedoman pengendalian penyakit infeksi saluran nafas akut, pemerintah melalui Direktorat Jenderal Bina Farmasi dan Alat Kesehatan juga melaksanakan program pengunaan obat rasional yang sudah berjalan dan terus dioptimalkan. Beberapa hal yang mendasari program ini adalah karena belum optimalnya penggunaan obat secara rasional pada fasilitas kesehatan dasar dan rujukan, gencarnya iklan dan pemasaran obat yang mempengaruhi peresepan obat oleh dokter dan swamedikasi oleh masyarakat, masih tingginya penggunaan antibiotika secara tidak rasional oleh tenaga kesehatan dan masyarakat sehingga bisa menimbulkan masalah resistensi, masih kurangnya kuantitas dan kualitas tenaga farmasi khususnya di fasilitas kesehatan dasar. (Depkes. 2014)

Tujuan yang ingin dicapai melalui program ini adalah untuk meningkatkan efektifitas dan efesiensi belanja obat di wilayah Provinsi maupun Kabupaten/ Kota, meningkatkan mutu pelayanan kefarmasian dalam mendukung pelayanan kesehatan, meningkatkan kepercayaan masyarakat terhadap mutu pelayanan kesehatan di sektor publik dan mencegah dampak penggunaan obat irrasional baik secara klinis, sosial ekonomi termasuk mencegah resistensi. (Depkes. 2014)

Data hasil pemantauan peresepan antibiotika untuk ISPA nonpneumonia di Puskesmas tahun 2013 untuk Provinsi Bali mencapai 46,7\%. Angka ini lebih tinggi dari batas maksimum nasional yang ditetapken Departemen Kesehatan Republik Indonesia yaitu 20\%. (Depkes. 2014). Artinya ada yang perlu diperbaiki dalam penatalaksanaan penyakit infeksi saluran pernafasan akut nonpneumonia ini, baik dalam hal pengobatannya maupun dalam pengendalian penyebaran penyakitnya.

Puskesmas sebagai sarana pelayanan kesehatan yamg menjadi rujukan pertama bagi masyarakat untuk mendapatkan pelayanan pengobatan dasar, memiliki peranan penting dalam pengendalian penggunaan antibiotika. Peranan Puskesmas didalam melakukan upaya kesehatan masyarakat maupun upaya kesehatan perseorangan dengan lebih mengutamakan upaya promotif dan preventif diharapkan mampu menekan penggunaan antibiotika.

Berdasarkan uraian diatas, penulis ingin melakukan penelitian tentang penggunaan antibiotika ini, khususnya untuk pengobatan ISPA nonpneumonia di Puskesmas.

\section{BAHAN DAN METODE}

Rancangan Penelitian. Penelitian ini termasuk ke dalam jenis penelitian non-eksperimental atau observasional yaitu penelitian berdasarkan datadata yang sudah ada tanpa melakukan perlakuan terhadap subyek uji. Rancangan analisa adalah secara deskriptif observasional yaitu untuk memperoleh gambaran tingkat penggunaan antibiotik pada pengobatan infeksi saluran pernafasan akut (ISPA) non-pneumonia. Hasil dari penelitian ini nantinya tidak digunakan untuk membuktikan hipotesis seperti pada penelitian analitik observasional atau eksperimental. Namun demikian, hasilnya nanti dapat digunakan sebagai awal untuk penelitian lebih lanjut.

Populasi adalah sebuah himpunan dari individu-individu, unit-unit, atau unsur-unsur yang mempunyai ciri-ciri yang sama. Populasi dalam penelitian ini adalah seluruh resep untuk pasien ISPA nonpneumonia yang dilayani dari tahun 2013 sampai dengan tahun 2015 yang berjumlah 4.962 resep

Sampel adalah himpunan bagian dari suatu populasi. Sampel dalam penelitian ini adalah resep untuk pasien ISPA nonpneumonia dari tahun 2013 sampai dengan tahun 2015 yang memenuhi kriteria inklusi.

Teknik sampling yang digunakan dalam penelitian ini adalah sampling non probabilitas dengan teknik purposive sampling, yaitu teknik penentuan sampel dengan kriteria tertentu. Pemilihan sampel berdasarkan kriteria inklusi dan eksklusi.

Kriteria inklusi sampel adalah resep untuk pasien yang berobat di Puskesmas Kediri II pada bulan januari sampai dengan Desember, dari tahun 
2013 sampai dengan tahun 2015 yang didiagnosa ISPA nonpneumonia yaitu: pilek (common cold), sinusitis, faringitis, tonsilitis, laringitis dan ISPA lainnya yang tidak spesifik.

Kriteria eksklusi adalah resep pasien ISPA nonpneumonia yang berobat di Puskesmas Kediri II pada bulan januari sampai dengan Desember, dari tahun 2013 sampai dengan tahun 2015 dengan diagnosa penyerta. Misalnya pasien yang didiagnosa ISPA nonpneumonia, tapi di waktu yang sama juga didiagnosa abses.

Metode. Kerangka konseptual dalam penelitian ini adalah sebagai berikut:

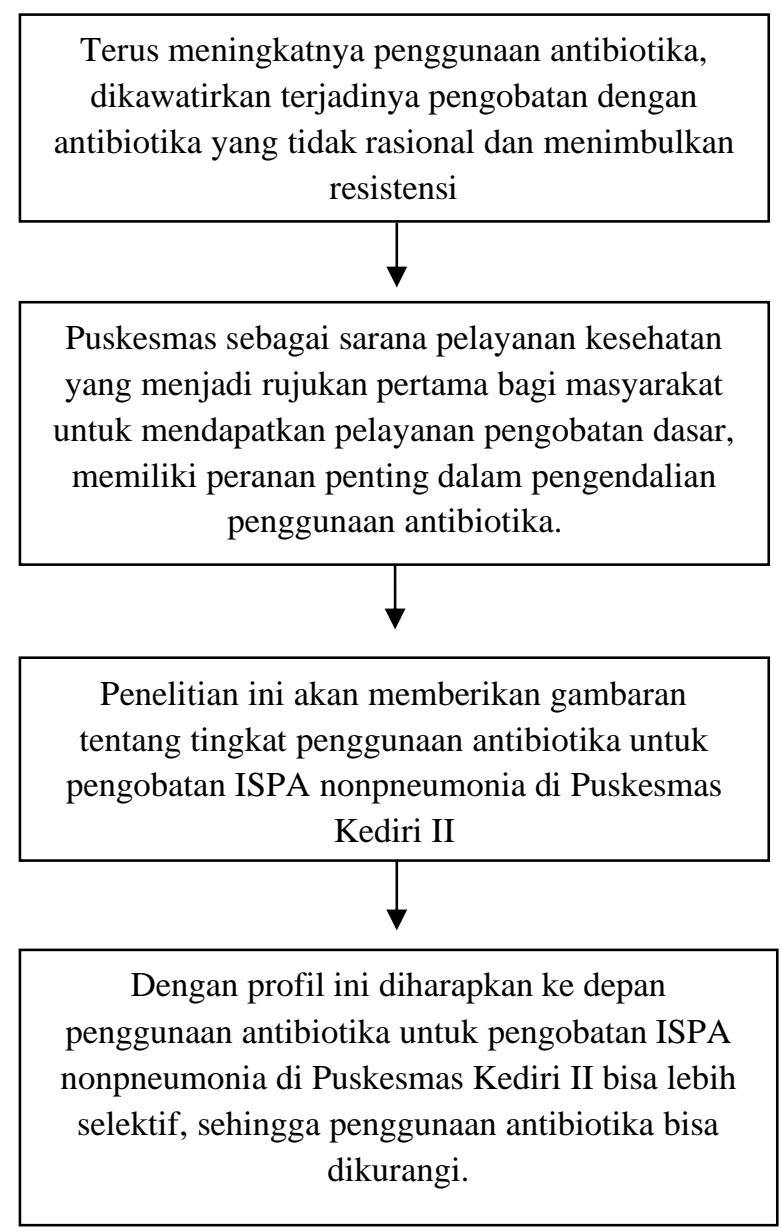

Gambar 1. Kerangka Konsep

Bahan. Antibiotika yaitu senyawa yang dihasilkan mikroorganisme yang dapat membunuh atau menghambat pertumbuhan bakteri lain. Dalam hal ini adalah antibiotika yang digunakan dalam pengobatan infeksi saluran pernafasan akut (ISPA) nonpneumonia.

Resep yaitu permintaan tertulis dari dokter atau dokter gigi kepada apoteker untuk menyediakan dan menyerahkan obat kepada pasien sesuai peraturan yang berlaku. Dalam penelitian ini resep yang dibuat oleh dokter dan tenaga kesehatan lainnya di Puskesmas Kediri II.

Pasien Infeksi Saluran Pernafasan Akut (ISPA) Nonpneumonia yaitu pasien yang didiagnosa menderita ISPA nonpneumonia, seperti: pilek (common cold), sinusitis, faringitis, tonsilitis, laringitis dan ISPA lainnya yang tidak spesifik dengan gejala batuk, pilek dan demam saja.

\section{HASIL}

Data Hasil Rekapitulasi Resep. Berdasarkan hasil pengambilan data yang dilakukan, diperoleh data sebagai berikut:

Tabel 1. Data Hasil Rekapitulasi Resep

\begin{tabular}{|c|c|c|c|c|}
\hline \multirow[b]{2}{*}{ No } & \multirow[b]{2}{*}{ Tahun } & \multirow{2}{*}{$\begin{array}{c}\text { Jumlah } \\
\text { Resep }\end{array}$} & \multicolumn{2}{|c|}{ Pengobatan } \\
\hline & & & $\begin{array}{c}\text { Dengan } \\
\text { Antibiotik }\end{array}$ & $\begin{array}{c}\text { Tanpa } \\
\text { Antibiotik }\end{array}$ \\
\hline 1 & 2013 & 867 & 747 & 120 \\
\hline 2 & 2014 & 931 & 825 & 106 \\
\hline 3 & 2015 & 726 & 598 & 128 \\
\hline & Total & 2.524 & 2.170 & 354 \\
\hline
\end{tabular}

Perhitungan. Untuk mencari tingkat penggunaan antibiotika pada pengobatan ISPA nonpneumonia dihitung dengan menggunakan rumus:

$$
X=\frac{A}{B}
$$

Dimana:

$\mathrm{X}=$ Tingkat penggunaan antibiotika

$\mathrm{A}=$ Jumlah sampel resep yang ada antibiotika

$\mathrm{B}=$ Jumlah sampel resep keseluruhan

\begin{tabular}{|c|c|c|}
\hline \multirow{2}{*}{$\begin{array}{l}\text { Tahun } \\
\text { 2013: }\end{array}$} & Diketahui: & $A=747$ resep \\
\hline & Dihitung: & $\begin{array}{l}\mathrm{B}=867 \text { resep } \\
\mathrm{X}=\ldots \ldots \ldots \ldots \ldots\end{array}$ \\
\hline \multirow{6}{*}{$\begin{array}{l}\text { Tahun } \\
\text { 2014: }\end{array}$} & & 747 \\
\hline & & $\begin{aligned} X= & ---------x 100 \% \\
& 867 \\
& =86,16 \%\end{aligned}$ \\
\hline & Diketahui: & $A=825$ resep \\
\hline & & $B=931$ resep \\
\hline & Dihitung: & $\begin{array}{c}X=\ldots \ldots \ldots \ldots \ldots \\
825\end{array}$ \\
\hline & & $\begin{array}{l}X=------x 100 \% \\
\quad 931 \\
=\mathbf{8 8 . 6 1 \%}\end{array}$ \\
\hline Tahun & Diketahui: & $\mathrm{A}=598$ resep \\
\hline
\end{tabular}




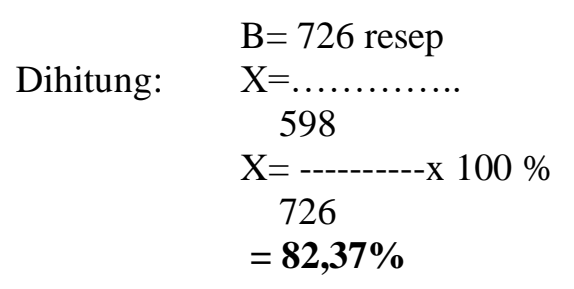

Berdasarkan hasil perhitungan yang dilakukan, diperoleh data sebagai berikut:

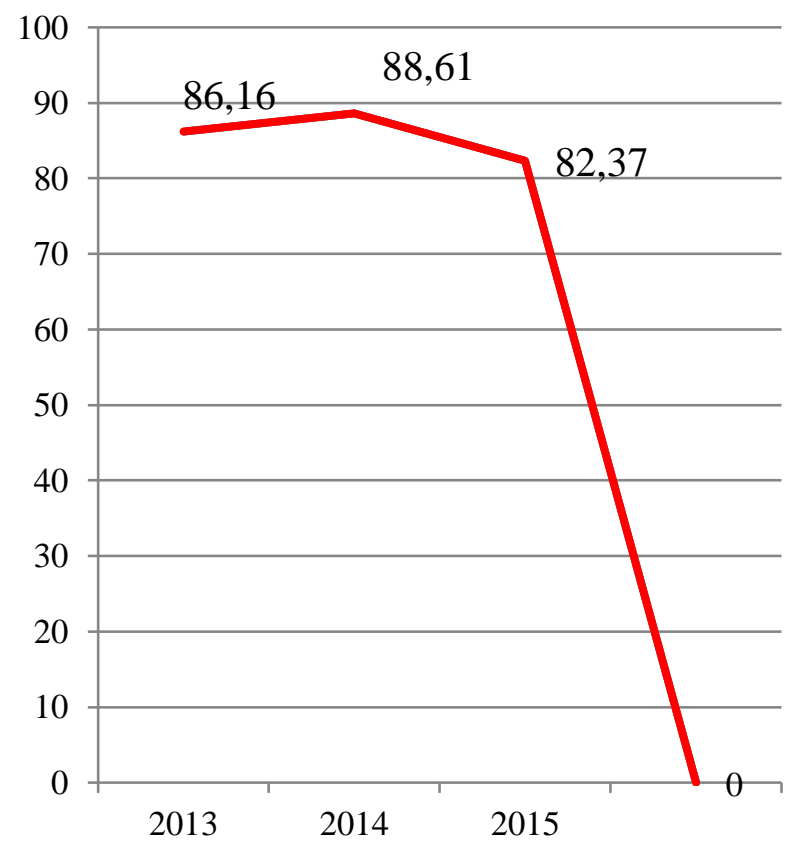

Data Penggunaan Antibiotika Untuk

Pengobatan ISPA. Berdasarkan hasil pengambilan data yang dilakukan, diperoleh data pengguanaan antibiotika untuk pengobatan infeksi saluran pernapasan akut nonpneumonia sebagai berikut:

Tabel 2. Data Jumlah Penggunaan Antibiotika

\begin{tabular}{lcccccc}
\hline & \multirow{2}{*}{ Nama } & & \multicolumn{4}{c}{ Jumlah Penggunan } \\
\cline { 3 - 6 } No & Antibiotika & Golongan & Tahun & Tahun & Tahun & \multirow{2}{*}{ Total } \\
& & & 2013 & 2014 & 2015 & (2014 \\
$\mathbf{1}$ & Amoxycillin & Penisilin & 716 & 755 & 542 & 2.013 \\
$\mathbf{2}$ & Cefadroxil & Cefalosporin & 7 & 47 & 37 & 91 \\
$\mathbf{3}$ & Ciprofloxacin & Quinolon & 9 & 10 & 10 & 29 \\
$\mathbf{4}$ & Corimoxazole & Sulfa & 15 & 13 & 9 & 37 \\
\hline
\end{tabular}

Tabel 3. Data Persentase Penggunan Antibiotika

\begin{tabular}{|c|c|c|c|c|c|c|}
\hline \multirow[b]{2}{*}{ No } & \multirow[b]{2}{*}{$\begin{array}{c}\text { Nama } \\
\text { Antibiotika }\end{array}$} & \multirow[b]{2}{*}{ Golongan } & \multicolumn{4}{|c|}{ Persentase Penggunaan } \\
\hline & & & $\begin{array}{c}\text { Tahun } \\
2013\end{array}$ & $\begin{array}{c}\text { Tahun } \\
2014\end{array}$ & $\begin{array}{c}\text { Tahun } \\
2015\end{array}$ & Total \\
\hline 1 & Amoxycillin & Pinisilin & 95,85 & 91,52 & 90,64 & 92,76 \\
\hline 2 & Cefadroxil & Cefalosporin & 0,94 & 5,70 & 6,19 & 4,19 \\
\hline 3 & Ciprofloxacin & Quinolon & 1,20 & 1,21 & 1,67 & 1,34 \\
\hline 4 & Corimoxazole & Sulfa & 2,01 & 1,58 & 1,51 & 1,71 \\
\hline & & & 100,00 & 100,00 & 100,00 & 100,00 \\
\hline
\end{tabular}

\section{PEMBAHASAN}

Penelitian ini bertujuan untuk memperoleh gambaran tentang penggunaan antibiotika pada pengobatan infeksi saluran pernafasan akut nonpneumonia. Seperti telah diuraikan sebelumnya bahwa terjadi kecendrungan peningkatan penggunaan antibiotika oleh masyarakat, baik karena peresepan oleh tenaga kesehatan ataupun swamedikasi. Hal ini menimbulkan kekhawatiran terjadinya penggunaan antibiotika yang tidak rasional yang bisa menimbulkan akibat yang tidak diinginkan, salah satunya terjadi resistensi.

Data yang dipublikasikan oleh Departemen Kesehatan Republik Indonesia, Direktorat Jenderal Bina Kefarmasian dan Alat Kesehatan, menunjukkan bahwa penggunaan antibiotika untuk pengobatan ISPA nonpneumonia tahun $2013 \mathrm{di}$ Provinsi Bali, mencapai angka 46,7\%. Hal ini menunjukkan bahwa tingkat penggunaan antibiotika untuk pengobatan ISPA nonpneumonia di Bali masih lebih tinggi dari batas maksimum nasional yang ditetapkan oleh Departemen Kesehatan, yaitu $20 \%$.

Berdasarkan teori penatalaksanaan pengobatan ISPA nonpneumonia menjelaskan bahwa penanganan ISPA nonpneumonia tidak serta merta menggunakan antibiotika, karena penyebab dari penyakit ini umumnya lebih dominan virus yang tidak memerlukan pengobatan dengan antibiotika. Langkah-langkah penanganan terhadap gejala yang timbul seperti batuk, flu, demam dan nyeri lebih dikedepankan dengan pemberian analgetik, antipiretik, antihistamin, dekongestan, antitusif ataupun ekspektoran, vitamin dan mineral untuk meningkatkan daya tahan tubuh dan menganjurkan pasien untuk istirahat dan menghindari paparan yang menimbulkan gangguan kesehatan, seperti merokok. Apa bila hal ini diperhatikan tentunya penggunan antibiotika bisa dikurangi.

Pengobatan dengan antibiotika memang dianjurkan apabila sudah dilakukan uji kultur atau tes laboratorium. Hal ini tentu perlu waktu, proses dan biaya. Belum lagi terkendala sarana prasarana dan tenaga kesehatan yang terbatas. Umumnya pasien tidak sabar mengalami gangguan dan ingin secepatnya bebas dari gangguan tersebut. Hal ini membuat masyarakat ataupun tenaga kesehatan mengambil keputusan yang cepat untuk menggunakan antibiotika, dengan harapan gangguan yang dialaminya segera teratasi dan bisa beraktivitas seperti biasa. 
Kementrian Kesehatan Republik Indonesia sudah menerbitkan pedoman umum penggunaan antibiotik. Pedoman ini hendaknya dijadikan acuan bagi tenaga kesehatan dalam memberikan antibiotika kepada pasien dengan mempertimbangkan pemberian antibiotika lini pertama dengan spektrum sempit, pada indikasi yang ketat, artinya ditemukan sindrom klinis yang mengarah pada keterlibatan bakteri tertentu yang paling sering menjadi penyebab infeksi.

Dari hasil penelitian diperoleh angka pengguaan antibiotika di Puskesmas Kediri II dari tahun 2013 sampai dengan tahun 2015 tidak menunjukkan kenaikan ataupun penurunan yang tinggi. Tahun 2013 tingkat penggunan antibiotika $86,16 \%$ dari jumlah kasus yang diteliti, tahun 2014 tingkat penggunaan antibiotika mengalami sedikit peningkatan dari tahun 2013 yaitu naik 2,45\% menjadi $88,61 \%$ dari jumlah kasus yang diteliti, dan tahun 2015 mengalami penurunan lagi 6,24\% dari tahun 2014 menjadi $82,37 \%$. Secara rata-rata prosentase penggunaan antibiotika dari tahun 2013 sampai dengan tahun 2015 mencapai 85,97\% dari total kasus ISPA Nonpneumonia yang diteliti.

Angka ini terlihat menarik untuk dilakukan penelitian lebih lanjut bila dihubungkan dengan teori tentang penatalaksanaan penyakit ISPA, dimana penanganannya lebih mengedepankan pengobatan tanpa antibiotika. Di sini perlu dikaji kerasionalannya. Tetapi bila dilihat dari segi penggunaan jenis antibiotika, sudah mempertimbangkan pengguaan antibiotika lini pertama. Hal ini dapat dilihat dari penggunaan Amoxycillin yang paling dominan.

Berdasarkan buku pedoman umum penggunaan antibiotik yang diterbitkan oleh Departemen Kesehatan, penggunaan antibiotika pada penanganan kasus ISPA ini masuk dalam penggunaan antibiotika untuk terapi empiris atau penggunaan antibiotika pada kasus infeksi yang belum diketahui jenis bakteri penyebabnya. Tenaga kesehatan dibenarkan memberikan antibiotika untuk mengeradikasi atau menghambat pertumbuhan bakteri yang diduga menjadi penyebab infeksi sebelum diperoleh hasil memeriksaan mikrobiologi. Indikasinya bila ditemukan sindrom klinis yang mengarah pada keterlibatan bakteri tertentu yang menjadi penyebab infeksi.

Sisi lain yang bisa dilihat dari hasil penelitian ini adalah tentang kebiasaan masyarakat didalam menangani masalah kesehatannya terutama jika menderita keluhan ISPA. Apakah begitu mengalami gejala ISPA sudah langsung memeriksakan diri ke Puskesmas atau menunggu beberapa hari setelah melakukan swamedikasi dan keluhanya bertambah baru memeriksakan diri ke Puskesmas. Tentunya ini memerlukan penelitian lebih lanjut, sehingga diperoleh data yang pasti. Karena hal ini akan berpengaruh pada keputusan tenaga kesehatan dalam memberikan pengobatan dengan antibiotika atau tidak. Jika lebih awal ditangani mungkin saja tidak akan diberikan pengobatan dengan antibiotika, sehingga penggunaan antibiotika bisa dikurangi.

Dari hasil wawancara yang dilakukan peneliti dengan tenaga kesehatan yang bertugas di Puskesmas Kediri II, diperoleh informasi bahwa umumnya pasien yang datang berobat sudah merasakan keluhan lebih dari satu hari dan sudah melakukan pengobatan swamedikasi ataupun sudah berobat ke tenaga kesehatan praktek swasta. Hal ini tentunya menjadi masalah bagi tenaga kesehatan di Puskesmas, apabila memberikan pengobatan tanpa antibiotika.

\section{SIMPULAN}

Dari hasil penelitian yang dilakukan dapat disimpulkan bahwa profil penggunaan antibiotika pada pengobatan infeksi saluran pernafasan akut nonpneumonia di Puskesmas Kediri II tahun 2013 sebesar 86,16\%, tahun 2014 sebesar 88,61\% dan tahun 2015 sebesar 82,37\%, dengan Amoxycillin menduduki peringkat tertinggi penggunaan antibiotika yaitu sebesar 92,76\%, Cefadroxil 4,19\%, Ciprofloxacin 1,34\% dan Cotrimoxazole 1,71\%.

\section{DAFTAR PUSTAKA}

Departemen Kesehatan RI, 2005, Pharmaceutical Care Untuk Penyakit Infeksi Saluran Pernafasan, Jakarta, Departemen Kesehatan RI. Direktorat Jenderal Bina Kefarmasian dan Alat Kesehatan.

Departemen Kesehatan RI, 2006, Pedoman Pengendalian Penyakit Infeksi Saluran Pernafasan Akut, Jakarta, Departemen Kesehatan RI. Direktorat Jenderal Pengendalian Penyakit \& Penyehatan Lingkungan.

Departemen Kesehatan RI, 2014, Kegiatan Subdit Penggunaan Obat Rasional, Jakarta, Departemen Kesehatan RI. Direktorat Jenderal Bina Kefarmasian dan Alat Kesehatan. 
Departemen Kesehatan RI, 2014, Panduan Praktik Klinis Bagi Dokter Di Fasilitas Pelayanan Kesehatan Primer, Jakarta, Departemen Kesehatan RI.

Kementrian Kesehatan RI, 2015, Pedoman Umum Penggunaan Antibiotik, Jakarta, Departemen Kesehatan RI. Direktorat Jenderal Bina Kefarmasian dan Alat Kesehatan.

Lawrence M. Tierney, Jr Stephen J. McPhee Maxine A. Papadakis, 2002, Diagnosa Dan Terapi Kedokteran (Penyakit Dalam), Diterjemahkan oleh Abdul Gofir, Jakarta, Salemba Medika.
Mary Kamienski, Jim Keogh, 2006, Farmakologi DeMYSTiFieD, Diterjemahkan oleh Ayu Sandhi, Jakarta, Rapha Publishing.

Nugroho, 2011, Farmakologi Obat-Obat Penting Dalam Pembelajaran Ilmu Farmasi dan Dunia Kesehatan, Jogjakarta, Pustaka Pelajar.

Nursalam, 2013, Metodelogi Penelitian Ilmu Keperawatan. Jakarta, Salemba Medika.

Zainuddin, 2011, Metodologi Penelitian Kefarmasian dan Kesehatan, Jakarta, Pusat Penebitan dan Percetakan Unair. 